\title{
Net removal of nitrogen through ingestion of phytoplankton by Atlantic menhaden Brevoortia tyrannus in Chesapeake Bay
}

\author{
Patrick D. Lynch*, Mark J. Brush, Elizabeth D. Condon, Robert J. Latour \\ Virginia Institute of Marine Science, College of William \& Mary, PO Box 1346, Gloucester Point, Virginia 23062, USA
}

\begin{abstract}
As filter-feeding planktivores, Atlantic menhaden Brevoortia tyrannus have the potential to influence water quality through ingestion of phytoplankton and assimilation of resultant nutrients. To evaluate the influence of young-of-the-year (YOY) and age-1+ menhaden in Chesapeake Bay, rates of phytoplankton ( $\mathrm{chl}$ a) ingestion and total dissolved nitrogen (TDN) excretion were measured experimentally across varying phytoplankton concentrations. Ingestion rates of YOY menhaden increased ( 0.03 to $3.85 \mu \mathrm{g} \mathrm{chl} \mathrm{a} \mathrm{fish}{ }^{-1} \mathrm{~min}^{-1}$ ) in response to increasing phytoplankton concentration (4.98 to $198.22 \mu \mathrm{g} \mathrm{chl} \mathrm{a} \mathrm{l^{-1 }}$ ), while age-1+ menhaden exhibited virtually no ingestion of the phytoplankton offered. For YOY menhaden, a type-III functional response model best described the relationship between ingestion rate and phytoplankton concentration. Excretion rates of TDN by YOY menhaden increased (0.93 to $3.92 \mu \mathrm{gN}$ fish ${ }^{-1} \mathrm{~min}^{-1}$ ) across phytoplankton concentration, and the relationship was best described by an asymptotic exponential model. By contrast, excretion rates were relatively constant for age-1+ menhaden. The YOY ingestion and excretion rate models were combined and rates of net removal of nitrogen across phytoplankton concentrations ranged from -1.73 to 29.85 and -1.73 to $131.58 \mu \mathrm{gN}$ fish ${ }^{-1} \mathrm{~min}^{-1}$ when the ratio of carbon-to-chlorophyll was 50 and 200, respectively. Results suggest that YOY menhaden focus their grazing on patches of elevated phytoplankton abundance and/or supplement their diet with other sources (e.g. zooplankton and detritus) to maintain a positive nitrogen balance. Population-level estimates of net nitrogen removal imply that menhaden play a minimal role regarding water quality in Chesapeake Bay.
\end{abstract}

KEY WORDS: Clupeidae $\cdot$ Filtration $\cdot$ Filter feeding $\cdot$ Functional response $\cdot$ Excretion $\cdot$ Nutrients Water quality $\cdot$ Eutrophication

\section{INTRODUCTION}

Describing the influence of filter feeders on the plankton community in aquatic ecosystems is fundamental to understanding nutrient cycling and trophic ecology, and therefore essential to effective ecosystem management (CBFEAP 2006). As human population growth accelerates in coastal regions, excess nutrient loading and the subsequent stimulation of primary productivity increasingly threaten the health of estuaries. This is especially relevant in Chesapeake Bay (USA), where continually increasing nutrient inputs have reduced water quality and substantially altered benthic habitats over the past century (Hagy et al. 2004, Kemp et al. 2005). With the dramatic disease and fishery related decline in biomass of the eastern oyster Crassostrea virginica, a historically abundant filterfeeder in Chesapeake Bay (Rothschild et al. 1994), management agencies have begun focusing attention on other primary consumers such as Atlantic menhaden Brevoortia tyrannus to assess their potential influence on water quality (CBP 2000).

Atlantic menhaden are considered a vital component of coastal and estuarine ecosystems along the east coast of North America. They travel in large schools and undertake extensive coast-wide seasonal migra- 
tions (Reintjes 1969, Nicholson 1978). A large portion of the migratory adult population is thought to aggregate off the coast of North Carolina in winter, and with the onset of spring, menhaden begin migrating northward. By summer they are stratified by age and size along the coast, with the larger, older, fish migrating the farthest north (Nicholson 1978, Quinlan et al. 1999). Spawning occurs at all times of the year and throughout the migratory range, but peak spawning is considered to occur during winter off the coast of North Carolina (Higham \& Nicholson 1964, Reintjes 1969, Ahrenholz 1991). Through a combination of diel vertical positioning and selective tidal stream transport (presence in the upper portion of the water column during flooding tides, and in the lower portion during ebbing tides), newly spawned larvae enter various coastal bays and estuaries (Forward et al. 1999) where they metamorphose into juveniles and remain for 6 to 8 mo before returning to sea (Reintjes 1969, Ahrenholz 1991).

As filter-feeders, menhaden pass water over highly specialized gill-rakers, allowing the removal of fine particulates from the water column (Peck 1893). Numerous studies have characterized the diets of juvenile and adult menhaden as being primarily comprised of phytoplankton, zooplankton, detritus and amorphous matter (Peck 1893, Richards 1963, Jeffries 1975, Edgar \& Hoff 1976, Lewis \& Peters 1984, 1994). Furthermore, using estimates of filtration capacity and in situ observations, other studies have determined that menhaden schools may significantly impact on the plankton community (McHugh 1967, Oviatt et al. 1972, Durbin \& Durbin 1975).

Menhaden also support a large reduction fishery targeting age-1+ fish for the processing of fish meal, oil and solubles in the Virginia portion of Chesapeake Bay (USA) and in offshore waters. Given menhaden's potential ecological importance as a filter feeder (Durbin \& Durbin 1998) and as a forage fish (Hartman \& Brandt 1995), these fishery removals may create a trade-off between demand for harvest and ecosystem health, which may be best addressed in an ecosystembased management (EBM) context. Implementation of EBM in Chesapeake Bay however requires a clear understanding of how the feeding ecology of Atlantic menhaden affects nutrient cycling and therefore water quality.

Although menhaden have the potential to improve water quality through filtration, they also return nutrients (predominately nitrogen) through excretion, which may be a negative feedback to the ecosystem. By considering filtration and excretion rates, Durbin \& Durbin (1998) estimated that 3 to $6 \%$ of the annual nitrogen export from Narragansett Bay, Rhode Island (USA: $4.16 \times 10^{5} \mathrm{~kg} \mathrm{~N}$ ) was due to menhaden assimilat- ing nitrogen and migrating out of the system. Therefore, when examining the effects of menhaden on water quality, rates of nitrogen ingestion and excretion must be considered.

To evaluate the influence of Atlantic menhaden on Chesapeake Bay water quality, laboratory experiments were conducted that measured particle ingestion and nitrogen excretion rates of young-of-the-year (YOY) and age-1+ menhaden. Ingestion rates of phytoplankton were modeled in the context of Holling's (1959, 1965) description of a predator's functional response to phytoplankton concentration; excretion rates of nitrogen were also modeled as a function of phytoplankton concentration. Using estimates of phytoplankton ingestion and nitrogen excretion, net phytoplanktonbased nitrogen removal rates were then calculated across the range of phytoplankton concentrations. While previous studies have estimated menhaden filtration and nitrogen excretion rates (Durbin \& Durbin 1975, 1981, Friedland et al. 1984), none have measured and modeled the functional response to natural Chesapeake Bay plankton assemblages over a range of concentrations.

\section{MATERIALS AND METHODS}

Specimen collection. YOY Atlantic menhaden were captured by cast net in spring 2007 in the lower York River, a tributary to the lower Chesapeake Bay (Fig. 1), and were staged as YOY by fork length (FL) and weight (means $\pm \mathrm{SD})(\mathrm{FL}=73.6 \pm 13.0 \mathrm{~mm}$, weight $=$ $5.2 \pm 2.5 \mathrm{~g}$, Reintjes 1969). Age- $1+$ menhaden ( $\mathrm{FL}=$ $188.7 \pm 19.7 \mathrm{~mm}$, weight $=95.2 \pm 33.6 \mathrm{~g}$ ) were also captured in spring 2007 by a commercial pound-net fisherman located near the mouth of the York River in Mobjack Bay (Fig. 1). All research specimens were held in a 1514 l circular tank on continuously flowing unfiltered York River water, thereby maintaining acclimation to natural conditions. Collection and experimental protocols involving Atlantic menhaden were approved by, and conducted in accordance with, the College of William \& Mary's Institutional Animal Care and Use Committee (protocol: IACUC-2005-0628-3-pdlync).

Experimental design. The experiments were performed over a narrow time period in June 2007 to maintain a relatively consistent temperature (mean $=$ $25.0^{\circ} \mathrm{C} \pm 1.4 \mathrm{SD}$ ) and plankton composition. This experimentation window represents a time in which menhaden are abundant and feeding at relatively high rates in Chesapeake Bay. Circular $341 \mathrm{l}$ tanks were used during each experiment. The tanks were equipped with sampling valves to minimize samplinginduced disturbances, and constant aeration to maintain suspension of plankton. Normally, 6 tanks were 


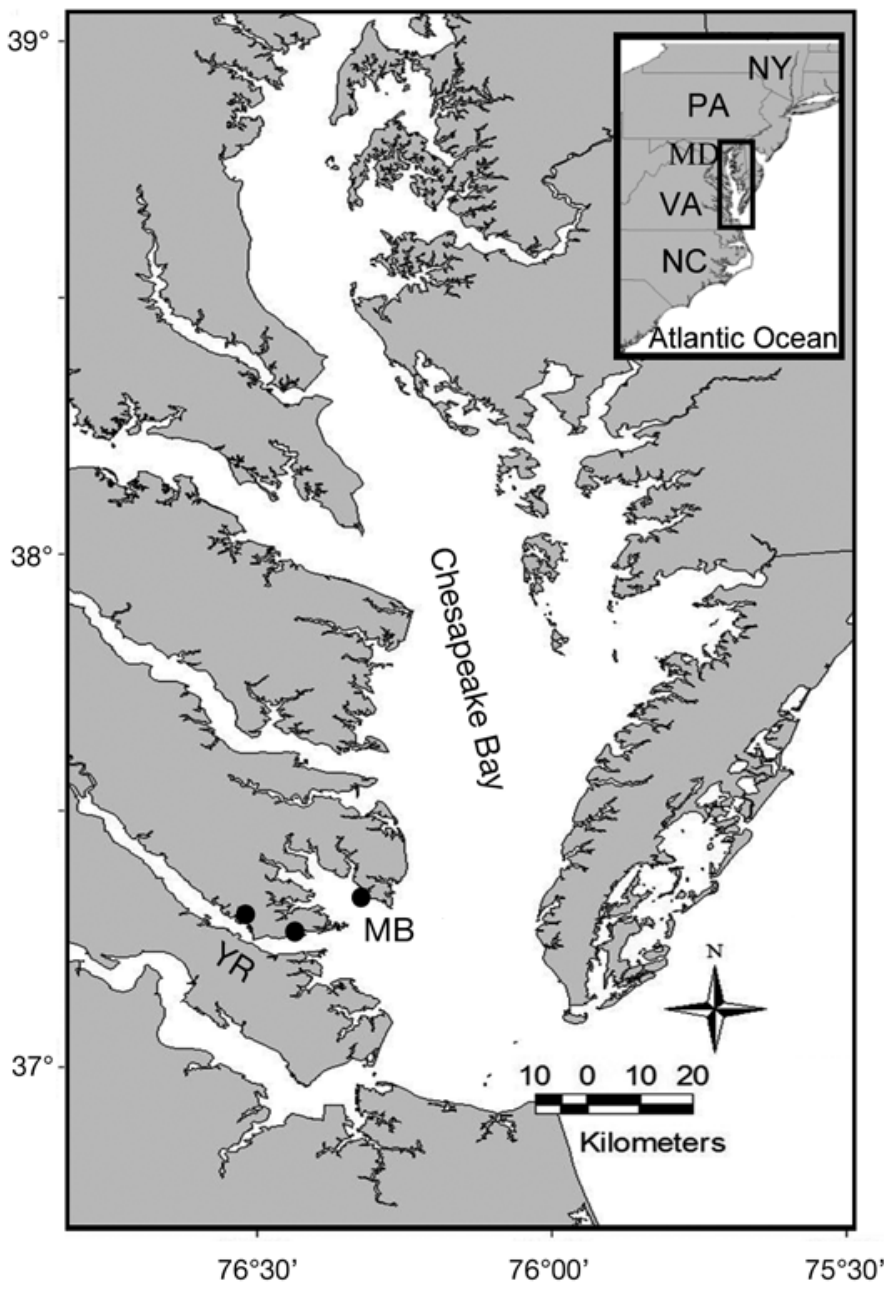

Fig. 1. Map of Chesapeake Bay, expanded from an inset map of the Mid-Atlantic United States. denote specimen collection sites from the York River (YR) and Mobjack Bay (MB)

filled with $200 \mathrm{l}$ of $1 \mu \mathrm{m}$ filtered York River water $48 \mathrm{~h}$ prior to the onset of an experiment. The $48 \mathrm{~h}$ holding period allowed fish to acclimate to experimental conditions (AFS 2004). For YOY experiments 15 fish, and for age-1+ experiments 3 fish, were transferred to 3 tanks each. Three remaining tanks without fish served as controls. Thus, each experiment was conducted at a given plankton concentration and had 2 trials (fish and no fish), with 3 replicate tanks for each trial. However, in 4 of the YOY experiments, 2 different plankton concentrations were evaluated simultaneously. In these experiments there were 4 trials ( 2 with fish and 2 without) with 3 replicates per trial for a total of 12 tanks.

Immediately following the acclimation period, all accumulated feces were removed by siphon, and a specific volume of filtered water (150 l in high plankton concentration experiments, and $100 \mathrm{l}$ in low plankton concentration experiments) was drained from each tank. The volume removed was then replaced with unfiltered York River water, and the $6 \mathrm{~h}$ experiment began immediately. Chlorophyll a (chl a) concentrations were estimated throughout the experiments and served as a proxy for phytoplankton biomass. In addition to these bulk estimates, a comprehensive analysis of the phytoplankton community was performed by directly counting the individual phytoplankters, and assigning them to a specific classification (autotrophic dinoflagellates, cryptophytes, cyanobacteria, diatoms, heterotrophic dinoflagellates) and size-range $(<7$, $7-15,15-30,>30 \mu \mathrm{m})$. To estimate nitrogen excretion rates, water samples were collected throughout the experiments and ammonium concentrations were measured. For 2 of the experiments (1 YOY and 1 age$1+)$, additional water samples were taken during the acclimation phase. These additional samples were taken after menhaden were in the experimental tanks for at least $24 \mathrm{~h}$, and were used to determine baseline non-feeding excretion rates for YOY and age-1+ fish. At the completion of each experiment, all fish lengths and weights were recorded. Overall, this is a general description of the experimental design; for specific details, see Appendix 1.

Ingestion rates. Clearance and ingestion rates were calculated from the change in plankton concentration throughout each experiment, and were expressed as volume of water cleared and amount of plankton ingested per fish per minute. Harvey (1937) described a relationship between exponentially decreasing phytoplankton concentrations and feeding by the copepod Calanus finmarchicus, and we used this relationship to estimate the 'volume of water swept free' in a unit of time (clearance rate). Previous experiments have deemed this relationship appropriate for representing clearance rates of adult and YOY menhaden (Durbin \& Durbin 1975, Friedland et al. 1984), prompting the adoption of this method to estimate filtration rates as follows:

$$
F=\frac{V}{t N}\left(\Delta c_{\text {adj }}\right)
$$

where $F$ is the clearance rate $\left(\mathrm{fish}^{-1} \mathrm{~min}^{-1}\right), V$ is the volume of water in the tank (l), $t$ is the duration of the experiment ( $\mathrm{min}), N$ is the number of fish in the tank, and $\Delta C_{\text {adj }}$ is the change from initial to final of the logtransformed plankton concentration, adjusted by the average change that occurred in tanks without fish:

$\Delta C_{\mathrm{adj}}=\left(\log C_{\mathrm{i}}-\log C_{\mathrm{f}}\right)_{\mathrm{fish}}-\left(\frac{1}{n} \sum_{j=1}^{n}\left[\left(\log C_{\mathrm{i}}-\log C_{\mathrm{f}}\right)_{\mathrm{nofish}}\right]_{j}\right)$

In Eq. (2), $C_{\mathrm{i}}$ and $C_{\mathrm{f}}$ represent the initial and final

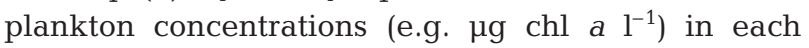
experimental tank, respectively. This model assumes 
an exponentially declining plankton concentration (i.e. continuous feeding at a constant rate throughout the experiment, thereby removing a constant proportion of the plankton per unit of time).

The amount of food ingested was then estimated using the following relationship (Båmstedt et al. 2000):

$$
I=F \times[\bar{C}]
$$

where $I$ is the ingestion rate $\left(\mu \mathrm{g} \mathrm{fish}^{-1} \mathrm{~min}^{-1}\right.$, for chl a) and $[\bar{c}]$ is the average prey concentration (e.g. $\mu \mathrm{g} \mathrm{chl} \mathrm{a}$ $\mathrm{l}^{-1}$ ) throughout an experiment, and was calculated from the equation:

$$
[\bar{c}]=\frac{C_{\mathrm{i}}\left(1-\mathrm{e}^{-\Delta C_{\mathrm{adj}}}\right)}{\Delta C_{\mathrm{adj}}}
$$

Functional response. Menhaden ingestion rates were modeled under the framework of Holling's (1965) 3 types of a predator's functional response to prey concentration. The type I model represents a linear relationship between ingestion rate and prey concentration. The type II model describes a decelerating response that saturates at an asymptote. The type III model is a sigmoid curve that represents an initial acceleration and then a deceleration of ingestion rate as prey concentration increases. The forms of the models used to relate $I$ to $C_{\mathrm{i}}$ were:

$$
\begin{aligned}
& \text { type I: } I=a C_{\mathrm{i}} \\
& \text { type IIa: } I=\frac{a C_{\mathrm{i}}}{1+a T C_{\mathrm{i}}} \\
& \text { type IIb: } I=\frac{a\left(C_{\mathrm{i}}-C_{0}\right)}{1+a T\left(C_{\mathrm{i}}-C_{0}\right)} \\
& \text { type III: } I=P_{1} \mathrm{e}^{\left(-P_{2} \mathrm{e}^{\left(-P_{3} c_{\mathrm{i}}\right)}\right)}
\end{aligned}
$$

where in Eqs. (5)-(6b), the parameter a represents the instantaneous encounter or attack rate and $T$ (Eq. 6a \& $6 \mathrm{~b}$ ) is the handling time ( $\mathrm{min}$ ) required for ingestion of prey. In Eq. (6b), $c_{0}$ is the density threshold below which no feeding occurs; Eq. (7) is a Gompertz equation where the 3 parameters $\left(P_{1}, P_{2}, P_{3}\right)$ simply govern the shape of the curve.

The models used herein were meant to be consistently phenomenological, and with the addition of Eq. (6b) are similar in form to those used by Wang et al. (2006). In a review of functional response models, Jeschke et al. (2002) identified nearly 50 different formulations of Holling's (1959) original type II model. While Jeschke et al. (2002) provided a mechanistic form of the type II model, it was noted in their study that the most commonly used formulations, including that proposed by Holling (1959), are essentially phenomenological (i.e. the parameters are not entirely explained mechanistically). Eq. (6b) represents an alternative version of the disc equation that allows for a density threshold below which no feeding occurs. Also, to be clear, Eq. (5) is a commonly used version of a linear functional response, but since it is unbounded it is technically different from the model described by Holling (1959).

The candidate models were fitted to the data and parameter estimates were derived using maximum likelihood estimation, assuming a normal probability density function. An information-theoretic approach to model selection was then used for selecting the model that best described the functional response (Burnham \& Anderson 2002). Akaike's information criterion, corrected for small sample size $\left(\mathrm{AIC}_{\mathrm{c}}\right)$, was used as follows:

$$
\mathrm{AIC}_{\mathrm{C}}=-2 \log (\ell(\hat{\theta}))+2 K+\frac{2 K(K+1)}{n-K-1}
$$

where $\ell(\hat{\theta})$ is the estimated maximized likelihood, $K$ is the number of estimable parameters and $n$ is the sample size. The model with $\Delta \mathrm{AIC}_{\mathrm{C}}=0$, where $\Delta \mathrm{AIC}_{\mathrm{C}}$ is the difference between the corresponding $\mathrm{AIC}_{\mathrm{C}}$ and the lowest $\mathrm{AIC}_{\mathrm{c}}$ of the candidate models, was selected as that which best fit the data. Models with $\Delta \mathrm{AIC}_{\mathrm{C}}$ values from 0 to 4 were considered to be strongly supported (Burnham \& Anderson 2002).

Nitrogen excretion rates. Total dissolved nitrogen excretion rates (TDN-ex) were calculated to estimate the degree to which nitrogen is returned to the ecosystem by menhaden. To accomplish this, ammonium excretion rates $\left(\mathrm{NH}_{4}{ }^{+}\right.$-ex) were estimated for each experimental tank using linear regression (Durbin \& Durbin 1981) and were converted to TDN-ex. The use of ambient York River water in the experimental tanks introduced organisms other than phytoplankton (e.g. bacteria, zooplankton) that may have caused background fluctuations of ammonium concentrations. Therefore, excretion rates estimated for tanks with menhaden were corrected by subtracting the mean excretion rate from each experiment calculated in tanks with no fish present.

In addition to ammonium, menhaden also excrete dissolved organic nitrogen (DON). Durbin \& Durbin (1981) showed that DON excretion rates were $43.7 \%$ of $\mathrm{NH}_{4}{ }^{+}$-ex for large adult menhaden in Narragansett Bay, Rhode Island (USA). We did not measure DON concentrations in the current study, but used the relationship described by Durbin \& Durbin (1981) to extrapolate estimated $\mathrm{NH}_{4}{ }^{+}$-ex rates to total DON-ex. Thus, TDN-ex was estimated by summing $\mathrm{NH}_{4}{ }^{+}$-ex and DON-ex. Nitrate and nitrite $\left(\mathrm{NO}_{x}\right)$ are also components of TDN; while $\mathrm{NO}_{x}$ concentrations were measured, only trace amounts were detectable throughout all experiments, so it was assumed that menhaden did not excrete an appreciable amount of $\mathrm{NO}_{x}$. 
Excretion rate models. TDN-ex was modeled as a function of initial phytoplankton (chl a) concentration. Initial chl a concentration was the independent variable (rather than amount of food ingested), because the overall goal of the study was to estimate the net removal of nitrogen through the ingestion of phytoplankton in response to phytoplankton concentration. Three candidate models were identified and corresponded to Holling's (1965) functional response models (type I, II, III) under the hypothesis that TDN-ex would mimic the response of $I$ to $C_{\mathrm{i}}$. The forms of the models differed from those in Eqs. (5) to (7) in that they allowed for baseline excretion when no feeding was occurring and phytoplankton were not present. Again, maximum likelihood was used for parameter estimation and $\mathrm{AIC}_{C}$ was used for model selection. The models used are as follows:

$$
\begin{gathered}
\text { TDN-ex }=\beta_{0}+\beta_{1} C_{\mathrm{i}} \\
\text { TDN-ex }=E_{\max }\left(1-\mathrm{e}^{-r\left(C_{\mathrm{i}}-E_{\text {base }}\right)}\right) \\
\text { TDN-ex }=P_{1} \mathrm{e}^{\left(-P_{2} \mathrm{e}^{\left(-P_{3} \mathrm{C}_{\mathrm{i}}\right)}\right)}
\end{gathered}
$$

where in Eq. (9) $\beta_{0}$ and $\beta_{1}$ are parameters representing the intercept and slope of the line, respectively, in Eq. (10) $E_{\max }$ is the maximum excretion rate, $r$ is the rate of increase to the maximum and $E_{\text {base }}$ allows for baseline nitrogen excretion when $C_{\mathrm{i}}$ is zero, and in Eq. (11) $P_{1}, P_{2}, P_{3}$ represent shape parameters.

Net nitrogen removal. The discrete estimates of TDN-ex and chl a ingestion rates were used to calculate rates of net removal of nitrogen $\left(R_{\mathrm{N}}\right)$ through phytoplankton ingestion by menhaden across the initial chl a concentrations used in the experiments. Cerco \& Noel (2004) presented a range of phytoplankton-based carbon-to-chlorophyll ratios (C:Chl) for Chesapeake Bay. Using the lower and higher monthly median C:Chl from their study (50 and $200 \mathrm{gC}$ $\mathrm{gChl}^{-1}$, respectively) and the carbon-to-nitrogen (C:N) Redfield composition for phytoplankton $(\mathrm{C}: \mathrm{N}=$ 106:16 molC molN ${ }^{-1}$, Redfield et al. 1966), low and high ingestion rates of nitrogen were calculated from the chl $a$ ingestion rates. The corresponding TDN-ex was then subtracted from the nitrogen ingestion rates to calculate $R_{\mathrm{N}}$. Also, a predictive model of $R_{\mathrm{N}}$ as related to initial chl a concentration was developed by combining the $\mathrm{AIC}_{\mathrm{C}}$-selected TDN-ex and functional response models. This model is adaptive to assumptions regarding the phytoplankton community, and can be used to evaluate the role of menhaden as related to water quality under many potential scenarios.

A portion of ingested nitrogen is returned to the system in fecal material; however, this feedback was not incorporated because it is likely that most fecal mater- ial sinks below the pycnocline before being remineralized. Fecal nitrogen may return to surface waters over a seasonal timescale, but our intent was to calculate instantaneous nitrogen removal rates to estimate the short-term influence of menhaden on water quality. Excluding fecal remineralization leads $R_{\mathrm{N}}$ to be slightly overestimated over the longer term.

Additional experiment. Initial analysis of clearance and ingestion rates across phytoplankton concentrations raised some concern regarding the willingness of age-1+ menhaden to feed during experiments. It is possible that age-1+ menhaden were unable to feed on the phytoplankton offered, or that the experimental conditions prevented these fish from behaving and feeding normally. Therefore, a single additional experiment was performed where the plankton offered were exclusively zooplankton (predominately Acartia tonsa) collected from the York River, and ingestion rates of zooplankton and excretion rates of nitrogen were estimated as described previously. The experiment duration was 3 instead of $6 \mathrm{~h}$, and was performed on YOY and age-1+ menhaden simultaneously $(n=3$ tanks per age group, with 3 tanks with no fish present to serve as controls).

\section{RESULTS}

\section{Phytoplankton community within experiments}

Chl a was measured as a proxy for phytoplankton biomass; the direct counts and classification of phytoplankton were used to estimate initial and final percent composition (by number and by weight) of the phytoplankton community for each experiment. Mean initial chl a concentration ranged from 4.98 to $198.22 \mathrm{\mu g} \mathrm{l}^{-1}$ for YOY experiments, and from 8.66 to $101.78 \mu \mathrm{g} \mathrm{l}^{-1}$ for age-1+ experiments. The total initial concentration of phytoplankton ranged from $1.18 \times 10^{5}$ to $5.56 \times 10^{5}$ cells $\mathrm{ml}^{-1}$, but the initial percent composition was relatively constant across all experiments, irrespective of chl a concentration and age-group of fish. Therefore, average percent composition was calculated by size-range and classification across all experiments for each menhaden age-group (Tables 1 \& 2). The associated initial biomasses of these classifications of phytoplankton were more variable (Tables 1 \& 2), because Thalassiosira weissflogii (a diatom) was added in differing amounts throughout the experiments, and the biomass of these cells contributed to the percent composition by weight more so than did the changing abundance of smaller cells. With the exception of cyanobacteria and cells $<7 \mu \mathrm{m}$, decreases in percent composition across experiments were observed for almost all size ranges and types of phytoplankton. 


\section{Ingestion rates}

The assumption that menhaden fed continuously and at a constant rate during experiments was verified for YOY fish through visual inspection of changes in chl a concentrations over time (Fig. 2a). The observed decline in chl a concentrations in tanks without fish (Fig. 2a), potentially due to zooplankton grazing and/or particle settling, emphasized the need for correcting the changes in plankton concentration in the tanks with fish present by the changes that occurred in tanks with no fish present. By incorporating this correction, any background changes that may have occurred are accounted for in the ingestion rate calculations. A clear indication of a trend in phytoplankton ingestion rates was not observed for age-1+ menhaden since observed changes in chl a concentrations over time were similar for tanks with and without fish (Fig. $2 \mathrm{~b})$. Mean chl a ingestion rates ranged from $<0.1 \mu \mathrm{g}$ fish $^{-1} \mathrm{~min}^{-1}$ at low initial chl a concentrations $(<15 \mu \mathrm{g}$

Table 1. Mean and standard error (SE) of initial and final percent composition by number and weight for various size-ranges of phytoplankton across all youngof-the-year (YOY) and age-1+ feeding experiments combined

\begin{tabular}{|c|c|c|c|c|c|}
\hline \multirow{2}{*}{$\begin{array}{l}\text { Experimen } \\
\text { type }\end{array}$} & \multirow{2}{*}{$\begin{array}{l}\text { Size } \\
\text { range }(\mu \mathrm{m})\end{array}$} & \multirow{2}{*}{\multicolumn{2}{|c|}{$\begin{array}{l}\text { By number } \\
\text { Initial } \pm \text { SE Final } \pm \text { SE }\end{array}$}} & \multirow{2}{*}{\multicolumn{2}{|c|}{$\begin{array}{l}- \text { By weight } \\
\text { Initial } \pm \text { SE } \quad \text { Final } \pm \text { SE }\end{array}$}} \\
\hline & & & & & \\
\hline YOY & $<7$ & $97.8 \pm 0.5$ & $98.2 \pm 0.6$ & $32.9 \pm 5.9$ & $53.5 \pm 8.3$ \\
\hline YOY & $7-15$ & $1.9 \pm 0.5$ & $1.7 \pm 0.6$ & $41.6 \pm 6.3$ & $34.5 \pm 7.0$ \\
\hline YOY & $15-30$ & $0.2 \pm 0.1$ & $0.1 \pm 0.0$ & $14.8 \pm 1.6$ & $6.4 \pm 1.7$ \\
\hline YOY & $>30$ & $0.0 \pm 0.0$ & $0.0 \pm 0.0$ & $10.7 \pm 2.7$ & $5.6 \pm 1.9$ \\
\hline Age-1+ & $<7$ & $93.5 \pm 3.5$ & $99.3 \pm 0.2$ & $41.1 \pm 9.3$ & $64.8 \pm 8.1$ \\
\hline Age-1+ & $7-15$ & $4.0 \pm 1.8$ & $0.4 \pm 0.2$ & $30.9 \pm 5.2$ & $16.4 \pm 4.6$ \\
\hline Age-1+ & $15-30$ & $2.4 \pm 1.7$ & $0.2 \pm 0.1$ & $24.5 \pm 5.7$ & $12.8 \pm 4.1$ \\
\hline Age-1+ & $>30$ & $0.1 \pm 0.0$ & $0.0 \pm 0.0$ & $3.5 \pm 1.3$ & $6.0 \pm 2.4$ \\
\hline
\end{tabular}

$\mathrm{l}^{-1}$ ) to almost $4 \mu \mathrm{g} \mathrm{fish}^{-1} \mathrm{~min}^{-1}$ at relatively high initial concentrations $\left(194 \mu^{-1} \mathrm{~g} \mathrm{l}^{-1}\right.$ ) for YOY menhaden; mean chl a ingestion rates never exceeded $1 \mu \mathrm{g} \mathrm{fish}{ }^{-1} \mathrm{~min}^{-1}$ for age-1+ menhaden at any concentration (Table 3 ). In the additional experiment, where zooplankton were the only plankton offered, YOY menhaden exhibited a relatively high filtration rate, and an even higher filtration rate of zooplankton was detected for age-1+ menhaden (Table 3).

\section{Functional response}

All competing functional response models were fitted to the chl a ingestion rate data, and the underlying assumptions associated with model fitting (normally distributed errors, homogeneity of variance, etc.) were verified through graphical diagnostics (residual and normal quantile-quantile plots). For YOY menhaden, the type III functional response model had a $\Delta \mathrm{AIC}_{\mathrm{C}}=0$, and no other models had a $\Delta \mathrm{AIC}_{\mathrm{C}}<4$ (Table 4). Therefore, of the candidate models, the type III functional response model best described the response of YOY ingestion rates to chl a concentrations. When fitted to the data, this model clearly captured the sigmoidal nature of the response (Fig. 3a). No attempts were made to fit functional response models to the age-1+ data because, with the exception of a single data point (experimental tank), there was essentially no calculated ingestion of phytoplankton by these fish (Fig. 3b).

Table 2. Mean and standard error (SE) of initial and final percent composition by number and weight for phytoplankton classifications across all YOY and age-1+ feeding experiments combined

\begin{tabular}{|c|c|c|c|c|c|}
\hline \multirow{2}{*}{$\begin{array}{l}\text { Experiment } \\
\text { type }\end{array}$} & \multirow{2}{*}{ Classification } & \multicolumn{2}{|c|}{$\longrightarrow$ By number -} & \multicolumn{2}{|c|}{ By weight } \\
\hline & & Initial $\pm \mathrm{SE}$ & Final $\pm \mathrm{SE}$ & Initial $\pm \mathrm{SE}$ & Final $\pm \mathrm{SE}$ \\
\hline YOY & Autotrophic dinoflagellate & $0.0 \pm 0.0$ & $0.0 \pm 0.0$ & $0.8 \pm 0.2$ & $0.1 \pm 0.1$ \\
\hline YOY & Heterotrophic dinoflagellate & $0.0 \pm 0.0$ & $0.0 \pm 0.0$ & $0.0 \pm 0.0$ & $0.1 \pm 0.1$ \\
\hline YOY & Cryptophyte & $0.1 \pm 0.0$ & $0.1 \pm 0.0$ & $0.2 \pm 0.0$ & $0.4 \pm 0.1$ \\
\hline YOY & Cyanobacteria & $97.4 \pm 0.5$ & $97.7 \pm 0.7$ & $29.1 \pm 5.9$ & $47.4 \pm 8.2$ \\
\hline YOY & Cyanobacteria chain & $0.4 \pm 0.2$ & $0.6 \pm 0.5$ & $0.5 \pm 0.3$ & $1.2 \pm 0.7$ \\
\hline YOY & Diatom & $1.9 \pm 0.4$ & $1.5 \pm 0.4$ & $61.8 \pm 5.0$ & $45.5 \pm 7.2$ \\
\hline YOY & Diatom chain & $0.2 \pm 0.1$ & $0.1 \pm 0.0$ & $7.6 \pm 2.4$ & $5.3 \pm 2.0$ \\
\hline Age-1+ & Autotrophic dinoflagellate & $0.0 \pm 0.0$ & $0.0 \pm 0.0$ & $0.8 \pm 0.5$ & $0.7 \pm 0.6$ \\
\hline Age-1+ & Heterotrophic dinoflagellate & $0.0 \pm 0.0$ & $0.0 \pm 0.0$ & $0.0 \pm 0.0$ & $0.1 \pm 0.1$ \\
\hline Age-1+ & Cryptophyte & $0.3 \pm 0.3$ & $0.1 \pm 0.0$ & $0.2 \pm 0.1$ & $0.2 \pm 0.1$ \\
\hline Age-1+ & Cyanobacteria & $94.3 \pm 2.2$ & $98.6 \pm 0.3$ & $40.4 \pm 9.2$ & $54.6 \pm 8.7$ \\
\hline Age-1+ & Cyanobacteria chain & $3.0 \pm 2.1$ & $0.1 \pm 0.1$ & $2.5 \pm 2.0$ & $0.1 \pm 0.1$ \\
\hline Age-1+ & Diatom & $1.4 \pm 0.4$ & $0.7 \pm 0.2$ & $37.0 \pm 8.6$ & $24.4 \pm 5.6$ \\
\hline Age-1+ & Diatom chain & $1.1 \pm 0.5$ & $0.6 \pm 0.2$ & $19.2 \pm 7.5$ & $20.0 \pm 6.8$ \\
\hline
\end{tabular}




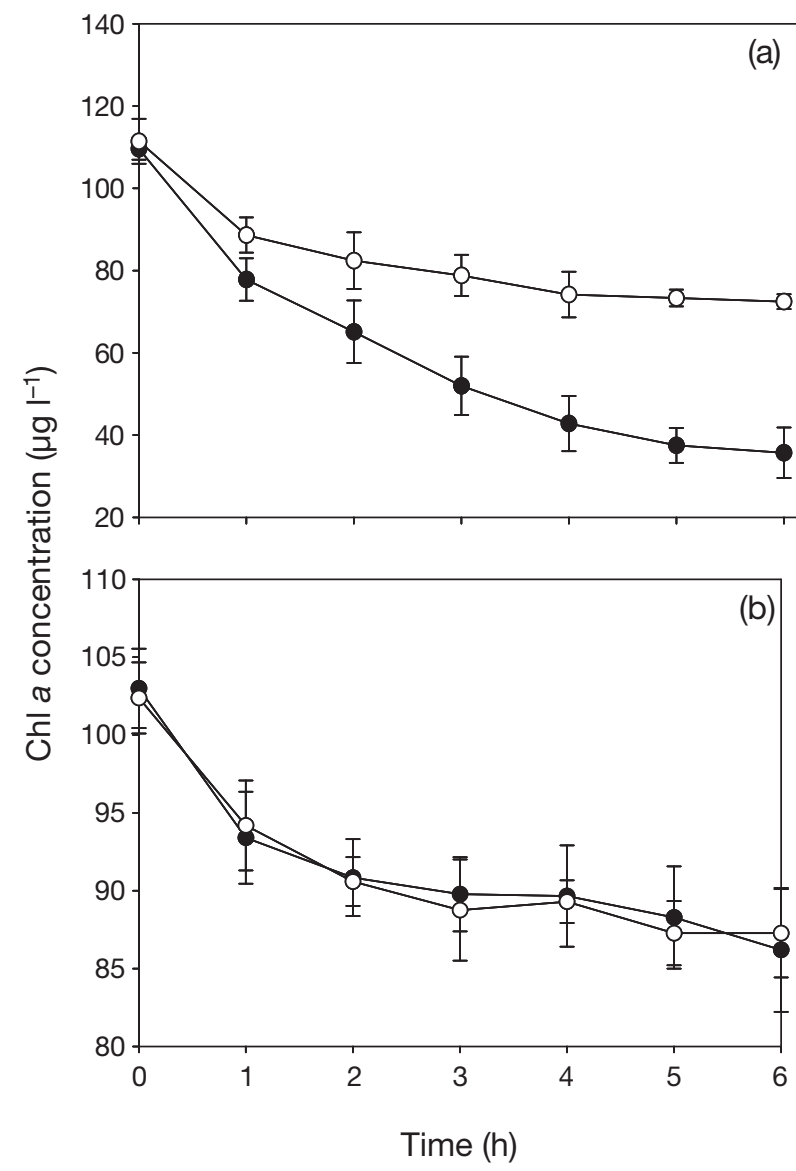

Fig. 2. Brevoortia tyrannus. Changes chl a concentrations (initially measured as fluorescence using a YSI 6600, then converted to extracted chl $a_{i}$ mean $\pm \mathrm{SD}$ ) throughout representative (a) YOY and (b) age-1+ menhaden feeding experiments.

0: tanks with fish present, O: tanks with no fish present

\section{Nitrogen excretion rates}

The observed changes in ammonium concentrations during feeding experiments verified the assumption of a linear increase in experimental tanks with menhaden (Fig. 4). Ammonium concentrations were higher in tanks with fish present at the beginning of each experiment, because while most of the water from the acclimation phase was exchanged with ambient water, some filtered water remained in the experimental tanks (typically 50 l) to allow the fish to continue swimming. In the tanks with fish present, this water likely had much higher ammonium concentrations than those without fish. Mean TDN-ex increased in response to initial chl a concentration for YOY menhaden, but remained relatively constant for age-1+ fish. YOY and age-1+ menhaden produced their highest excretion rates during the experiment where zooplankton was offered exclusively (Table 3).

\section{Excretion rate models}

TDN-ex increased with chl a concentration for YOY menhaden. Model selection indicated that the asymptotic exponential model best described the response of the 3 candidate models (Table 5, Fig. 5a), but the linear model was also strongly supported $\left(\mathrm{AIC}_{\mathrm{C}}=2.06\right)$. For age-1+ menhaden TDN-ex were higher (18.88 to 28.25 $\mu \mathrm{gN}$ fish ${ }^{-1} \mathrm{~min}^{-1}$ ) than those of YOY menhaden (1.33 to $5.63 \mu \mathrm{gN}$ fish ${ }^{-1} \mathrm{~min}^{-1}$ ) (Table 5); however, for age-1+ fish TDN-ex did not increase with chl a concentration (Fig. 5b) and no attempts were made to model these data.

\section{Net removal of nitrogen}

Discrete estimates of net removal rates of phytoplankton-based nitrogen $\left(R_{\mathrm{N}}\right)$ were calculated for YOY menhaden only, since there was essentially no measured ingestion of phytoplankton by age-1+ menhaden. Mean $R_{\mathrm{N}}$ was negative at low chl a concentrations, indicating a net release of nitrogen when phytoplankton was not abundant. Maximum and potentially extreme $R_{\mathrm{N}}\left(131.57 \mu \mathrm{gN} \mathrm{fish}^{-1} \mathrm{~min}^{-1}\right.$ ) occurred when chl a concentrations were high (194.22 $\mu \mathrm{g}$ $\mathrm{l}^{-1}$ ) and the assumed $\mathrm{C}: \mathrm{Chl}$ was $200 \mathrm{gC}_{\mathrm{gChl}}{ }^{-1}$ (Table 6, Fig. 6).

A predictive model of $R_{\mathrm{N}}$ as a function of chl a concentration was developed by combining the models selected as best representative of ingestion and excretion by YOY menhaden as follows:

$R_{\mathrm{N}}=\left[\left(\frac{\mathrm{C}: \mathrm{Chl}}{\mathrm{C}: \mathrm{N}}\right)\left(\frac{14}{12}\right)(\right.$ type III $\left.)\right]-[0.74(\mathrm{AE})+0.26(\mathrm{~L})]$

In Eq. (12), type III is the functional response model of chl a ingestion rates (Eq. 7) converted to nitrogen ingestion rates using estimates of $\mathrm{C}$ : Chl (Cerco \& Noel 2004) and C:N (Redfield et al. 1966) for phytoplankton. The molar conversion term (14/12) is also required

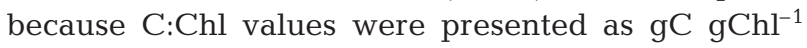
and $\mathrm{C}: \mathrm{N}$ values were $\mathrm{mol} \mathrm{C} \mathrm{mol} \mathrm{Cl}^{-1} \mathrm{~N}$. The second term is the weighted average of the 2 models selected as representative of TDN-ex, where $\mathrm{AE}$ represents the asymptotic exponential model (Eq. 10), L represents the linear model (Eq. 9) and 0.74 and 0.26 are the corresponding model probabilities (Table 5).

\section{DISCUSSION}

Clearance and ingestion rates of total chl a were calculated over a range of initial phytoplankton concentrations for both YOY and age-1+ Atlantic menhaden., The only comparative study of clearance rates of phytoplankton by YOY menhaden was conducted by 
Table 3. Brevoortia tyrannus. Mean and standard error (SE) of chl a clearance $(F)$ and ingestion $(I)$ rates, and total dissolved nitrogen excretion (TDN-ex) rates for YOY and age-1+ menhaden over a range of initial mean phytoplankton ( $\mathrm{chl}$ a) and zooplankton concentrations (each mean was calculated from $\mathrm{n}=3$ experimental tanks). Baseline experiments were conducted in the absence of plankton, and as indicated by a dash, TDN-ex was not measured in all experiments. $\mathrm{NA}=$ not applicable

\begin{tabular}{|c|c|c|c|c|}
\hline \multicolumn{5}{|c|}{ Natural plankton assemblage } \\
\hline $\begin{array}{l}\text { Experiment } \\
\text { type }\end{array}$ & $\begin{array}{l}\text { Initial chl a } \\
\text { conc. }\left(\mu \mathrm{g} \mathrm{l}^{-1}\right)\end{array}$ & $\begin{array}{c}F \pm S E \\
\left(1 \mathrm{fish}^{-1} \mathrm{~min}^{-1}\right)\end{array}$ & $\begin{array}{c}I \pm \mathrm{SE} \\
\left(\mu \mathrm{g} \mathrm{fish}^{-1} \mathrm{~min}^{-1}\right)\end{array}$ & $\begin{array}{l}\text { TDN-ex } \pm \text { SE } \\
\left(\mu \mathrm{gN} \text { fish }^{-1} \mathrm{~min}^{-1}\right)\end{array}$ \\
\hline YOY: Baseline & NA & NA & NA & $1.73 \pm 0.12$ \\
\hline YOY & 4.98 & $0.01 \pm 0.00$ & $0.03 \pm 0.00$ & - \\
\hline YOY & 9.14 & $0.01 \pm 0.00$ & $0.07 \pm 0.01$ & - \\
\hline YOY & 14.17 & $0.01 \pm 0.00$ & $0.08 \pm 0.01$ & $1.33 \pm 1.15$ \\
\hline YOY & 17.85 & $0.01 \pm 0.00$ & $0.14 \pm 0.01$ & - \\
\hline YOY & 64.87 & $0.03 \pm 0.00$ & $1.34 \pm 0.11$ & $3.30 \pm 0.14$ \\
\hline YOY & 106.53 & $0.04 \pm 0.01$ & $2.65 \pm 0.09$ & $4.77 \pm 0.55$ \\
\hline YOY & 127.29 & $0.05 \pm 0.00$ & $3.45 \pm 0.26$ & $5.63 \pm 0.31$ \\
\hline YOY & 194.22 & $0.03 \pm 0.00$ & $3.85 \pm 0.23$ & $4.06 \pm 0.70$ \\
\hline Age-1+: Baseline & ie NA & NA & NA & $27.41 \pm 2.96$ \\
\hline Age-1+ & 8.66 & $0.02 \pm 0.01$ & $0.12 \pm 0.04$ & - \\
\hline Age-1+ & 18.05 & $0.00 \pm 0.00$ & $0.01 \pm 0.01$ & - \\
\hline Age-1+ & 19.04 & $0.00 \pm 0.00$ & $0.00 \pm 0.00$ & $18.88 \pm 3.94$ \\
\hline Age-1+ & 55.77 & $0.00 \pm 0.00$ & $0.00 \pm 0.00$ & - \\
\hline Age-1+ & 101.78 & $0.01 \pm 0.01$ & $0.83 \pm 0.83$ & $28.25 \pm 3.87$ \\
\hline \multicolumn{5}{|c|}{ Zooplankton fed exclusively } \\
\hline $\begin{array}{l}\text { Experiment } \\
\text { type }\end{array}$ & $\begin{array}{l}\text { Initial zoop. } \\
\text { onc. (no. } \mathrm{l}^{-1} \text { ) }\end{array}$ & $\begin{array}{c}F \pm \mathrm{SE} \\
\left(1 \mathrm{fish}^{-1} \mathrm{~min}^{-1}\right)\end{array}$ & $\begin{array}{c}I \pm \mathrm{SE} \\
\left(\text { no. } \mathrm{fish}^{-1} \mathrm{~min}^{-1}\right)\end{array}$ & $\begin{array}{l}\text { TDN-ex } \pm \text { SE } \\
\left(\mu g N \text { fish }^{-1} \mathrm{~min}^{-1}\right)\end{array}$ \\
\hline YOY & 8.90 & $0.04 \pm 0.02$ & $0.33 \pm 0.16$ & $9.18 \pm 1.99$ \\
\hline Age-1+ & 7.83 & $0.33 \pm 0.05$ & $1.94 \pm 0.95$ & $38.10 \pm 3.30$ \\
\hline
\end{tabular}

Table 4. YOY functional response model rankings. Model likelihood $\left(\mathrm{e}^{\left.-0.5 \times \Delta \mathrm{AIC}_{\mathrm{c}}\right)}\right.$ is a metric for determining strength of evidence for each model and $W$ is the associated model probability calculated as the model likelihood divided by the sum of all model likelihoods. $\mathrm{AIC}_{\mathrm{c}}$ : Akaike's information criteria, corrected for small sample size

\begin{tabular}{|lccrrrrr|}
\hline Model & $\begin{array}{c}\text { No. of } \\
\text { parameters }\end{array}$ & $\mathrm{n}$ & $-\ln (\ell)$ & $\mathrm{AIC}_{\mathrm{c}}$ & $\Delta \mathrm{AIC}_{\mathrm{c}}$ & $\begin{array}{c}\text { Model } \\
\text { likelihood }\end{array}$ & $W$ \\
\hline Type I & 2 & 42 & -34.72 & -65.13 & 44.94 & 0.00 & 0.00 \\
Type IIa & 3 & 42 & -36.13 & -65.62 & 44.45 & 0.00 & 0.00 \\
Type IIb & 4 & 42 & -46.70 & -84.32 & 25.74 & 0.00 & 0.00 \\
Type III & 4 & 42 & -59.57 & -110.07 & 0.00 & 1.00 & 1.00 \\
\hline
\end{tabular}

itatively however, the lower clearance rates (0.01 to $0.06 \mathrm{l} \mathrm{fish}^{-1} \mathrm{~min}^{-1}$ ) reported for small phytoplankton $(<7 \mu \mathrm{m})$ by Friedland et al. (1984) were similar in magnitude to the highest clearance rates estimated in the present study. This general agreement is likely due to the high percentage of small phytoplankton present in the ambient water provided in the experiments (Tables 1 $\& 2$ ). While diatoms comprise a substantial proportion of the phytoplankton community in Chesapeake Bay annually, the smaller phytoplankters (dinoflagellates, cyanobacteria, etc.) often dominate in late spring and summer (Marshall et al. 2005). Thus, the clearance and ingestion rates presented herein likely reflect the influence of menhaden predation on total phytoplankton during these seasons in Chesapeake Bay. The rates reported by Friedland et al. (1984) better describe responses to individual species of phytoplankton however. Furthermore, potentially in response to eutrophication, cyanobacteria and other smaller phytoplankters have been increasing in abundance in Chesapeake Bay in recent years (Marshall et al. 2005). This trend may be compromising the ability of menhaden to improve water quality through filtration, since they are less efficient at ingesting smaller particles.

For age-1+ menhaden, the only comparative study of clearance rates of phytoplankton was conducted by Durbin \& Durbin (1975) on fish from Narragansett Bay, Rhode Island (USA). Again, due to the aforementioned differences in experimental protocols only qualitative comparisons of the results are possible. In the present study,

Friedland et al. (1984) on fish collected from Chesapeake Bay, and was based on experimental protocols originally established by Durbin \& Durbin (1975). Numerous methodological differences exist between the present study and Friedland et al. (1984) that preclude quantitative comparisons of clearance rates at various phytoplankton concentrations. Specifically, clearance rates in the earlier study were calculated in terms of numbers of particles rather than concentration of chl a. Other unique aspects of the present study include the use of ambient and correction of clearance rates for background changes in concentrations. Qual- essentially no ingestion or clearance of phytoplankton was measured for age-1+ menhaden, where Durbin \& Durbin (1975) did report clearance rates for adult menhaden, but only when feeding on larger species of phytoplankton. They estimated that adult menhaden have a minimum particle size threshold for filtration between 13 and $16 \mu \mathrm{m}$. The initial percentage compositions of phytoplankton by size range (Table 1) indicated that these larger phytoplankton cells and chains were present in the experiments, but perhaps in such a small percentage that any ingestion by age-1+ menhaden had a negligible impact on total chl a concentra- 


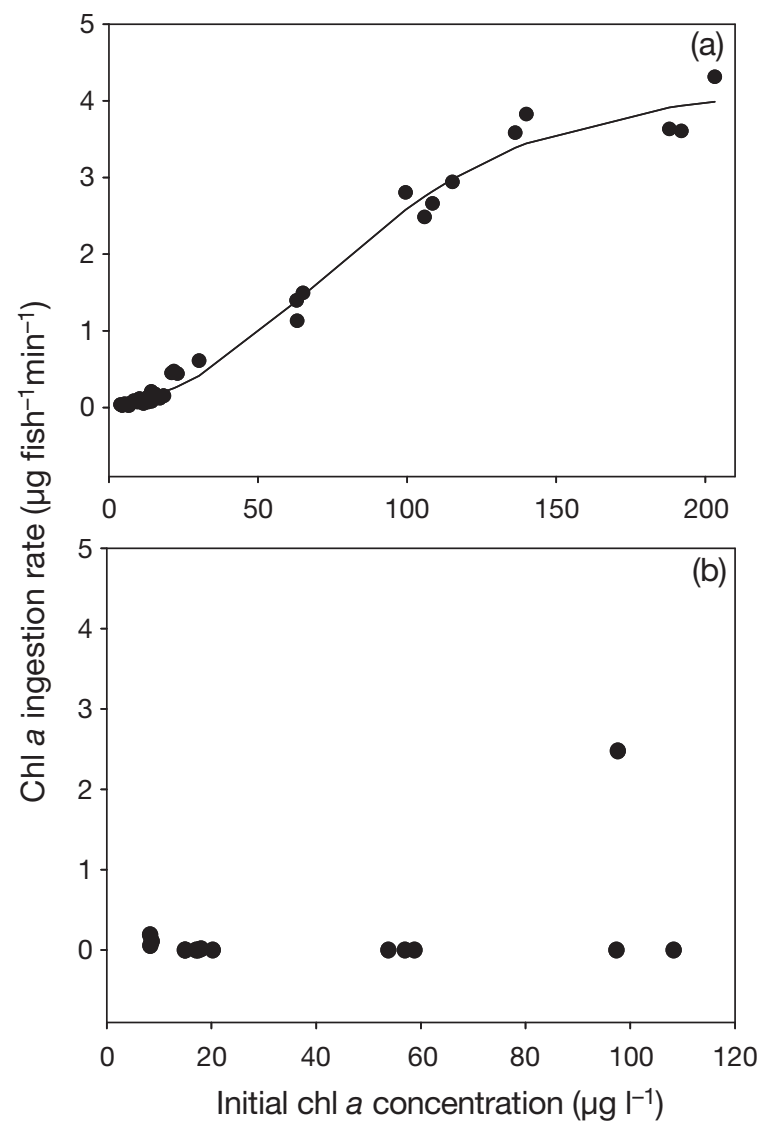

Fig. 3. Brevoortia tyrannus. Individual estimates of ingestion rates of total chl a for (a) YOY and (b) age-1+ menhaden over a range of initial chl a concentrations. The solid line (a) represents the type III functional response model (Eq. 7) fitted to the YOY ingestion rate data with parameter $(P)$ estimates \pm SE: $P_{1}=4.16 \pm 0.11, P_{2}=4.63 \pm 0.29, P_{3}=0.02 \pm 0.00$

tions. In fact, the only appreciable clearance rates measured for age-1+ menhaden occurred in the experiment where zooplankton was offered exclusively (Table 3). Therefore, as suggested by Durbin \& Durbin (1998), the removal of zooplankton and large phytoplankton by schools of adult menhaden may actually enhance the growth of smaller phytoplankton in the ecosystem by releasing grazing pressure from zooplankton.

The clearance and ingestion rates reported for YOY and age-1+ fish are also corroborated by a recent morphological analysis of the ontogenetic development of Atlantic menhaden gill raker feeding structures (Friedland et al. 2006). The estimate of minimum branchiospinule spacing (i.e. structures forming sieve apertures that govern particle size retention) for YOY menhaden was approximately 7 to $8 \mu \mathrm{m}$, though this age-class has been shown

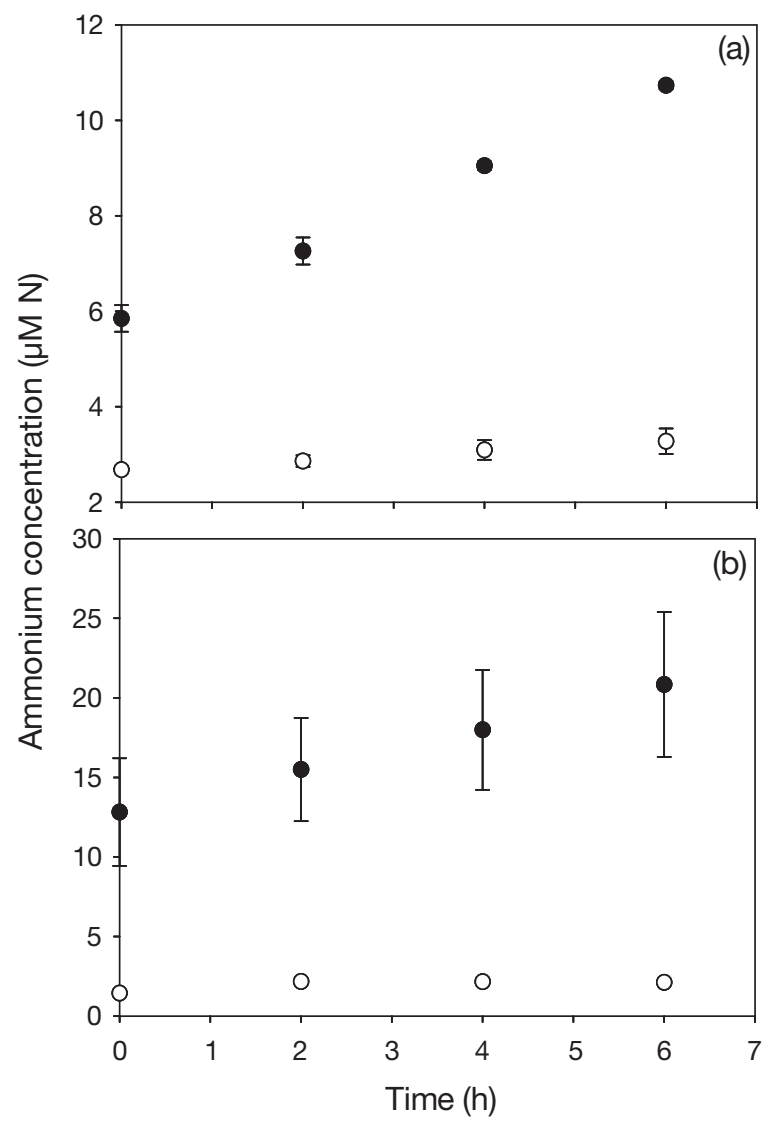

Fig. 4. Brevoortia tyrannus. Changes in mean $( \pm \mathrm{SD})$ ammonium concentrations over time within experimental tanks for representative (a) YOY and (b) age-1+ menhaden feeding experiments. - tanks with fish present, and O: tanks with no fish present

to filter particles smaller than $7 \mu \mathrm{m}$ (Friedland et al. 1984), likely due to particle clumping and crossflow filtration (Sanderson et al. 2001). The minimum branchiospinule spacing reported for age-1+ menhaden however, was between 15 and $20 \mu \mathrm{m}$, which potentially explains why clearance and ingestion rates of total phytoplankton were negligible for these fish. Furthermore, the changes in percent composition of phytoplankton across the experiments presented addi-

Table 5. YOY nitrogen excretion rate model rankings. Model likelihood $\left(\mathrm{e}^{-0.5 \times}\right.$ $\Delta \mathrm{AIC}_{\mathrm{c}}$ ) is a metric for determining strength of evidence for each model and $W$ is the associated model probability calculated as the model likelihood divided by the sum of all model likelihoods

\begin{tabular}{|lccccccc|}
\hline Model & $\begin{array}{c}\text { No. of } \\
\text { parameters }\end{array}$ & $\mathrm{n}$ & $-\ln (\ell)$ & $\mathrm{AIC}_{\mathrm{c}}$ & $\Delta \mathrm{AIC}_{\mathrm{c}}$ & $\begin{array}{c}\text { Model } \\
\text { likelihood }\end{array}$ & $W$ \\
\hline Linear & 3 & 18 & 13.64 & 34.99 & 2.06 & 0.36 & 0.26 \\
$\begin{array}{l}\text { Asymptotic } \\
\text { exponential }\end{array}$ & 4 & 18 & 10.93 & 32.93 & 0.00 & 1.00 & 0.74 \\
$\begin{array}{l}\text { Sigmoid } \\
\text { Sigmoid }\end{array}$ & 4 & 18 & 17.35 & 45.78 & 12.85 & 0.00 & 0.00 \\
\hline
\end{tabular}




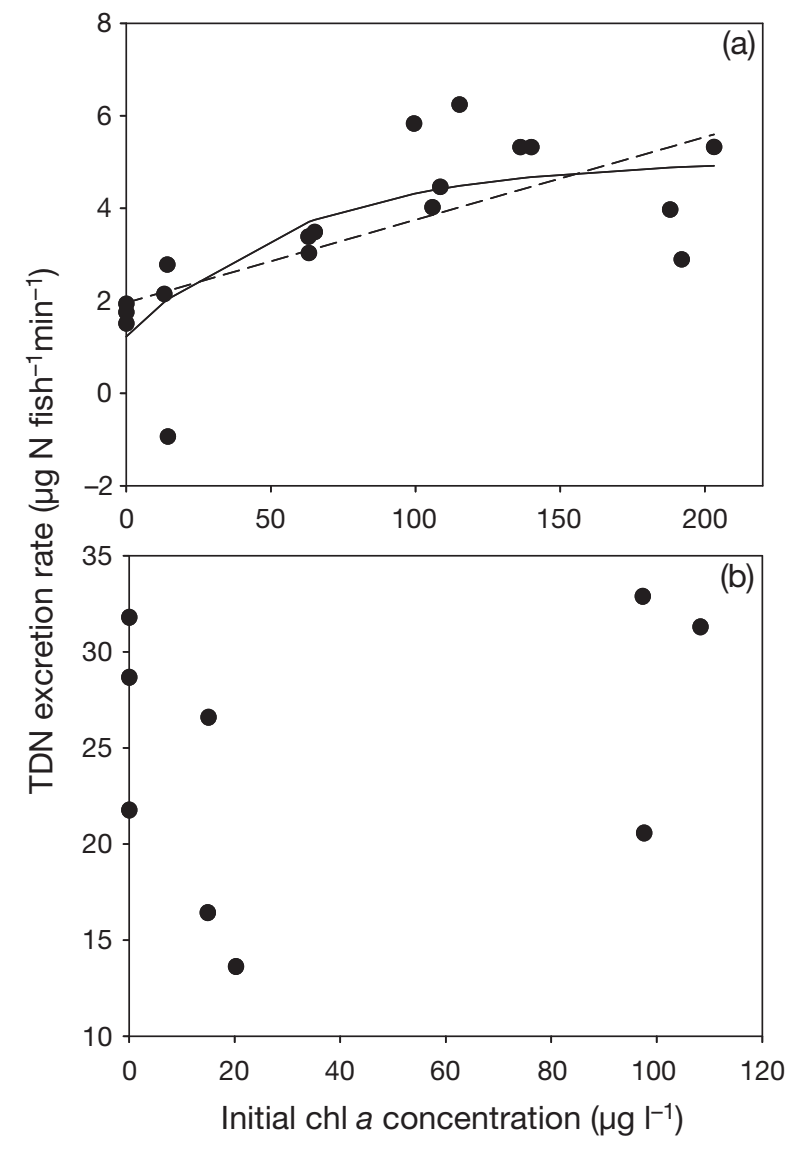

Fig. 5. Brevoortia tyrannus. Total dissolved nitrogen excretion rates for (a) YOY and (b) age-1+ menhaden over a range of initial phytoplankton ( $\mathrm{chl}$ a) concentrations. The solid and dashed lines (a) represent the fits of the asymptotic exponential (Eq. 10) and linear (Eq. 9) excretion rate models to the YOY data, respectively. Parameter estimates $\pm \mathrm{SE}$ are $E_{\max }=$ $5.05 \pm 0.67, r=0.02 \pm 0.01, E_{\text {base }}=-16.78 \pm 12.47$ for the asymptotic exponential model, and are $\beta_{0}=1.96 \pm 0.49, \beta_{1}=$ $0.02 \pm 0.00$ for the linear model

tional evidence of size-selective filtration. Since increases were seen for particles $<7 \mu \mathrm{m}$, the larger particles were consumed in higher proportions by YOY and age-1+ menhaden (Table 1). However, the relative changes in percent composition were greater for age1+ menhaden, indicating greater selection for larger particles than YOY menhaden. The change in percent composition also serves as evidence that age-1+ menhaden were feeding during the experiments, but apparently were not removing enough phytoplankton biomass to substantially reduce chl a concentrations.

Field-based analyses of menhaden diets should elucidate the ontogenetic shift in the minimum particle size that can be consumed. While phytoplankton and zooplankton have been detected in the diets of YOY and age-1+ fish, many of these studies have concluded that a large proportion of the menhaden diet (80-90\%) is comprised of amorphous matter (Lewis \& Peters
Table 6. Brevoortia tyrannus. Mean and standard error (SE) of net removal rates of phytoplankton-based nitrogen $\left(R_{\mathrm{N}}\right)$ by YOY menhaden over a range of initial mean chl a concentrations using 2 separate carbon-to-chlorophyll ratios (C:Chl) (each mean was calculated from $\mathrm{n}=3$ experimental tanks)

\begin{tabular}{|c|c|c|c|}
\hline \multirow{2}{*}{$\begin{array}{l}\text { Experiment } \\
\text { type }\end{array}$} & \multirow{2}{*}{$\begin{array}{l}\text { Initial chl a } \\
\text { conc. }\left(\mu g \mathrm{l}^{-1}\right)\end{array}$} & \multicolumn{2}{|c|}{$R_{\mathrm{N}} \pm \mathrm{SE}\left(\mu \mathrm{gN} \mathrm{fish}^{-1} \mathrm{~min}^{-1}\right)$} \\
\hline & & $\mathrm{C}: \mathrm{Chl}=50$ & $\mathrm{C}: \mathrm{Chl}=200$ \\
\hline YOY & 0.00 & $-1.73 \pm 0.12$ & $-1.73 \pm 0.12$ \\
\hline YOY & 14.17 & $-0.61 \pm 1.13$ & $1.56 \pm 1.12$ \\
\hline YOY & 64.87 & $8.51 \pm 0.82$ & $43.94 \pm 3.69$ \\
\hline YOY & 106.53 & $18.57 \pm 0.35$ & $88.59 \pm 2.75$ \\
\hline YOY & 127.29 & $24.76 \pm 2.62$ & $115.91 \pm 9.58$ \\
\hline YOY & 194.22 & $29.85 \pm 1.42$ & $131.58 \pm 7.50$ \\
\hline
\end{tabular}

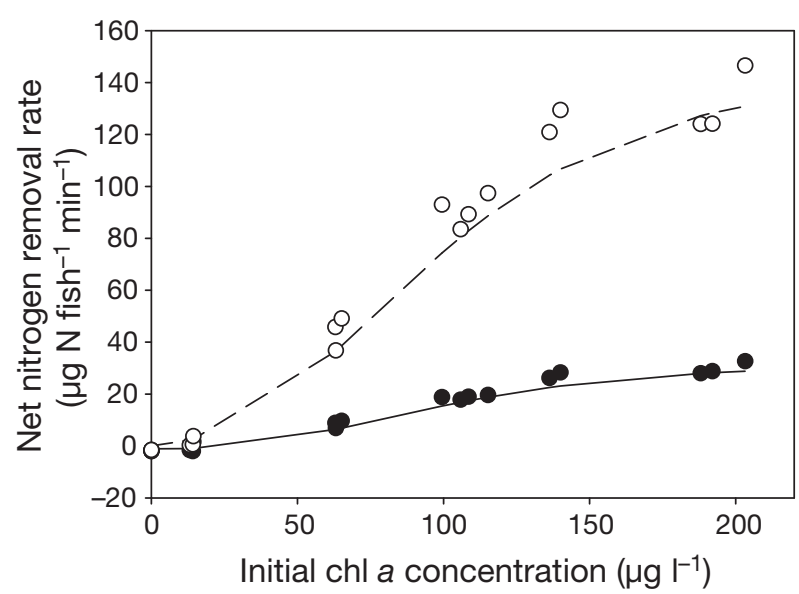

Fig. 6. Brevoortia tyrannus. Rates of net removal of phytoplankton-based nitrogen for YOY menhaden over a range of chl a concentrations. All circles represent calculated rates. Carbon-to-chlorophyll $(\mathrm{C}: \mathrm{Chl})=200$ for open circles and 50 for filled circles. Lines represent the rates as predicted by the $R_{\mathrm{N}}$ model (Eq. 12), where C: $\mathrm{Chl}=200$ for the dashed line and 50 for the solid line

1994, and references therein). This may be a result of difficulties associated with the application of visual techniques to analyze menhaden stomach contents and a lack of reporting of sizes of individual plankton. Chemical techniques have been applied (Jeffries 1975), but they cannot determine particle sizes of dietary components. Thus, a future study that characterizes the menhaden diet in terms of particle size would facilitate an understanding of how the ontogenetic change in filtration capability is reflected in menhaden diets.

Functional responses have been characterized for fishes, and often the type II response was solely considered (Ivlev 1961, Houde \& Schekter 1980, Miller et al. 1992). While this assumption may have been appropriate for these studies, the selection of a type III response for menhaden emphasizes the need for testing competing models. Holling (1965) revealed a general trend 
among functional response models as representative of 3 types of organisms (type I: filter feeders; type II: invertebrates; type III: vertebrates). Despite this classification, the functional responses of fishes summarized by Holling (1965) were all type II. However, criticisms of the studies in which these responses were reported led Holling (1965) to conclude that the response is more likely type III for fishes. Further, when considering the findings of Durbin et al. (1981) the type III response appears most likely for menhaden. They measured menhaden swimming speeds in response to chl a concentration, and described a hyperbolic response within relatively low chl a concentrations $\left(<11 \mu \mathrm{g} \mathrm{l}^{-1}\right)$. Across this range of low chl a concentrations, increases in swimming speeds likely result in an acceleration of ingestion rates, potentially explaining the shape of the type III functional response curve. In fact, Dunbrack \& Giguere (1987) suggested that the findings of Durbin et al. (1981) support their hypothesis of a bioenergetic basis for the type III response.

A type III functional response is certainly not restricted to menhaden; rather, it is becoming a common characterization for many organisms. This response has been observed in ecosystem-wide studies evaluating marine predators in the presence of multiple prey sources (Koen-Alonso \& Yodzis 2005, Smout \& Lindstrøm 2007), as well as studies in experimental settings with a single type of prey (Márquez et al. 2007). The latter scenario is more similar to this study, despite the fact that numerous species of phytoplankton were present in the experiments (measuring ingestion rates of total chl a effectively treated all phytoplankton as a single food source). Also, type III responses have been observed for terrestrial organisms such as insects (Hassell et al. 1977, Akre \& Johnson 1979, Wang et al. 2006) and mice (Schauber et al. 2004). Thus, it appears that sigmoidal responses of predation rates to prey densities may be common to many species in a variety of ecosystems.

Explanations for the biological significance of the type III functional response are varied. Holling (1965) suggested that the sigmoid shape is representative of the predator 'learning' the value of a certain prey type at low prey concentrations. Once learned, the predator increases consumption rates of that prey, or switches to feeding on that prey type from another prey type, either of which may result in the sigmoid response. The aforementioned bioenergetic basis for a type III response (Dunbrack \& Giguere 1987) indicates that feeding may be energetically inefficient for YOY menhaden at low phytoplankton concentrations, but as concentrations increase, accelerated feeding becomes more beneficial. In other words, the energetic demand associated with aggressive foraging may exceed the caloric intake afforded by low plankton concentra- tions. Since predation rates are not relaxed at low prey concentrations with type I and type II responses, they may be too costly for menhaden in terms of bioenergetics. Another potential explanation for the type III response may be that filtration efficiency is poor at very low phytoplankton concentrations, but then quickly increases as concentration increases. This phenomenon would incorporate the particle aggregation effects discussed by Friedland et al. (2006). Whether relaxing predation rates at low prey concentrations is an active or passive occurrence, the type III response has been described as a mechanism capable of stabilizing prey abundance (Murdoch 1969, Oaten \& Murdoch 1975, Landry 1981, Kempf et al. 2008).

In addition to describing the functional response, this is the first study to report excretion rates of TDN for YOY menhaden. Durbin \& Durbin (1981), estimated nitrogen excretion rates for adult menhaden, and express their rates as $\mu g \mathrm{~N}$ (g dry weight) ${ }^{-1} \mathrm{~h}^{-1}$ rather than $\mu \mathrm{gN}$ fish ${ }^{-1} \min ^{-1}$. Since Durbin \& Durbin (1981) reported a relationship between wet weight and dry weight (dry weight $=0.334 \times$ wet weight), the rates reported herein can be converted, facilitating comparisons between studies. While this relationship may exhibit substantial temporal and spatial variability, and may not hold true for YOY fish, it is the only known estimate that relates wet weight to dry weight for menhaden. A mean dry weight per fish was estimated for each experiment for converting TDN-ex. Baseline TDN-ex was then estimated to be 94.96 and $45.97 \mu \mathrm{gN}$ (g dry weight) $)^{-1} \mathrm{~h}^{-1}$ for YOY and age-1+ menhaden, respectively, and the maximum converted TDN-ex for YOY menhaden [277.51 $\mu \mathrm{gN}$ (g dry weight) ${ }^{-1} \mathrm{~h}^{-1}$ ] was associated with the second highest YOY ingestion rate (3.45 $\mu \mathrm{g} \mathrm{fish} \mathrm{sin}^{-1}$, Table 3), while the age-1+ maximum [124.90 $\mu \mathrm{gN}$ (g dry weight) ${ }^{-1} \mathrm{~h}^{-1}$ ] occurred during the additional experiment with zooplankton exclusively. These results are particularly interesting, because TDN-ex were higher for age-1+ menhaden when expressed on a per fish basis (Table 3, Fig. 5); however, on a per gram basis, they are much greater for YOY menhaden. Furthermore, there are discrepancies when the converted rates are compared with the results of Durbin \& Durbin (1981). Baseline TDN-ex for age-1+ fish was much greater than the baseline estimate [10.72 $\mu \mathrm{gN}$ (g dry weight $)^{-1} \mathrm{~h}^{-1}$ ] reported by Durbin \& Durbin (1981), but maximum TDN-ex was less than their maximum rate observed for feeding fish, which was 17 times their baseline measurement [approximately $170 \mu \mathrm{gN}$ (g dry weight) ${ }^{-1} \mathrm{~h}^{-1}$ ]. There are potential explanations for these observed differences. Baseline excretion was measured after $24 \mathrm{~h}$ without food, but Durbin \& Durbin (1981) allowed 36 h to elapse. Determining which rates are most representative of baseline excretion in the wild would require 
additional research on the amount of time that menhaden go without food in nature. Also, the higher maximum excretion rate observed by Durbin \& Durbin (1981) may be due to age-1+ menhaden feeding at a lower maximum intensity in the present study.

For YOY menhaden, the emergence of the asymptotic exponential model as the best description of the excretion rate response indicates a saturation of TDNex at high chl a concentrations. It is likely that the time associated with the physiological process of excretion causes the increasing excretion rate to decelerate to a maximum. It should be noted however that strong support was also given to the linear model of YOY excretion rates, but the variability observed at high concentrations renders it difficult to discern the exact nature of the response at those levels. The best representation of the response may result from a weighted model average of the 2 .

By combining the ingestion and excretion rate models, Eq. (12) can be used to predict net removal of nitrogen by YOY menhaden as a function of chl a concentration, while allowing flexibility in the C:Chl and $\mathrm{C}: \mathrm{N}$ ratios considered. For the 2 scenarios of phytoplankton-based C:Chl used (50 and 200), the lower value is more reflective of monthly median $\mathrm{C}$ : Chl during the late spring and summer months in Chesapeake Bay (Cerco \& Noel 2004); this is also the time of highest YOY menhaden abundance. Therefore, depending on the concentration of chl $a$, it is likely that during late spring through summer YOY menhaden generate a net flux of phytoplankton-based nitrogen ranging from -1.73 to $29.85 \mu \mathrm{gN}$ fish ${ }^{-1} \mathrm{~min}^{-1}$ (Table 6). Based on long-term monitoring data from the US Environmental Protection Agency's Chesapeake Bay Program (www. chesapeakebay.net), annual average bay-wide surface chl a concentrations are approximately $9.8 \mu \mathrm{g} \mathrm{l^{-1 }}$, which corresponds to a net nitrogen removal rate of $-1.29 \mu \mathrm{gN}$ fish $^{-1} \mathrm{~min}^{-1}$. This suggests that YOY menhaden must either supplement their diet with sources other than phytoplankton (e.g. zooplankton and detritus) and/or actively seek out phytoplankton blooms with higher chl a concentrations to maintain a positive nitrogen balance. If feeding on phytoplankton alone, Eq. (12) suggests that the YOY nitrogen balance becomes positive only above a chl a concentration of $30.45 \mu \mathrm{g} \mathrm{l}^{-1}$, which is typical of spring and summer blooms in the Chesapeake. However, Peters and Schaaf (1981) concluded that the energetic demand of juvenile menhaden cannot be met through phytoplankton alone; thus, a complete reliance on phytoplankton seems unlikely.

Extrapolating the range of nitrogen removal to the ecosystem for comparison with total nitrogen load requires reliable estimates of YOY menhaden population abundance in Chesapeake Bay. This quantity is presently unknown and extremely difficult to estimate with certainty; however, the most recent Atlantic menhaden stock assessment conducted by the Atlantic States Marine Fisheries Commission (ASMFC 2006) generated estimates of numbers of YOY (age-0) menhaden along the entire US Atlantic coast. Over the 10 yr preceding the assessment (1995-2005) this number ranged from 5.4 to 14.9 billion, with a mean of 9.4 billion fish. Applying this mean value and assuming that the entire coast-wide stock resides in Chesapeake Bay and feeds continuously, net nitrogen removal via phytoplankton ingestion would range from -23.4 to $404 \mathrm{t} \mathrm{N} \mathrm{d}^{-1}$ over the range of chl a concentrations used in this study (4.98-198.22 $\left.\mu \mathrm{g} \mathrm{l}^{-1}\right)$. Mean daily nitrogen loads from the watershed, point sources, and atmosphere to Chesapeake Bay range from 247 to $585 \mathrm{t} \mathrm{N} \mathrm{d}^{-1}$, based on Boynton et al. (1995) and more recent data from the Chesapeake Bay Program and United States Geological Survey's River Input Monitoring Database (http://va.water.usgs.gov/chesbay/ RIMP/index.html). Thus, under the extreme scenario of 9.4 billion fish feeding continuously, YOY menhaden represent a substantial source of nitrogen for phytoplankton at low chl a concentrations (contributing up to an additional $9.5 \%$ of mean $\mathrm{N}$ load) and a considerable sink at high concentrations (removing up to 69 to $100 \%$ of daily $\mathrm{N}$ inputs).

However, the entire coast-wide stock does not live in the bay, and while there is no clear understanding of their spatial distribution, the range of nitrogen removal for YOY menhaden is smaller than that computed above. For instance, if $50 \%$ of the stock resided in the bay, net nitrogen removal would range from -11.7 to $202 \mathrm{t} \mathrm{N} \mathrm{d}^{-1}$, and the range for $10 \%$ of the stock would be -2.3 to $40.4 \mathrm{t} \mathrm{N} \mathrm{d}^{-1}$. Furthermore, given a mean chl a concentration of $9.8 \mathrm{\mu g}^{-1}$ in the bay, actual nitrogen removal is likely towards the lower end of the computed range for each scenario, suggesting that menhaden probably do not play a large role in nitrogen removal, and may actually represent a source of nitrogen for phytoplankton.

To evaluate the role of menhaden regarding water quality in the context of the Chesapeake Bay ecosystem, comparisons were made to oysters and zooplankton, the other major grazers in the bay. We are unaware of similar bay-wide net removal rates for these grazers, but published estimates of clearance rates facilitate valuable comparisons. Under the assumption of continuous feeding by the entire coast-wide YOY population, the YOY clearance rates from Table 3 were used to estimate population-level clearance rates ranging from $1.4 \times 10^{8}$ to $6.8 \times 10^{8} \mathrm{~m}^{3} \mathrm{~d}^{-1}$. For $50 \%$ and $10 \%$ of the population, clearance rates fall to $6.8 \times 10^{7}$ to $3.4 \times 10^{8} \mathrm{~m}^{3} \mathrm{~d}^{-1}$ and $1.4 \times 10^{7}$ to $6.8 \times 10^{7} \mathrm{~m}^{3} \mathrm{~d}^{-1}$, respectively. Using modeled oyster clearance rates and bio- 
mass estimates in Chesapeake Bay (Fulford et al. 2007), we estimate that oyster filtration ranges from $1.5 \times 10^{8}$ to $8.0 \times 10^{8} \mathrm{~m}^{3} \mathrm{~d}^{-1}$; similar to the range for YOY menhaden if the entire coast-wide population resides in the bay, but exceeding menhaden by an order of magnitude under the $10 \%$ scenario. We estimated zooplankton clearance rates to range from $6.3 \times$ $10^{8}$ to $6.2 \times 10^{9} \mathrm{~m}^{3} \mathrm{~d}^{-1}$ using modeled bay-wide clearance rates and estimates of biomass (Bundy et al. 2006). This range exceeds that for oysters and menhaden, regardless of the proportion of the coast-wide menhaden population inhabiting Chesapeake Bay.

It is important to stress that the population-level estimates for menhaden are highly uncertain due to uncertainty in YOY population sizes in the bay, the exclusion of $\mathrm{N}$ recycling due to fecal decomposition as previously discussed, the sensitivity of YOY nitrogen balance to chl a concentrations, and the apparent need of YOY menhaden to ingest sources other than phytoplankton which we have not fully quantified. If better population estimates become available, improved estimates of nitrogen removal would best be generated with a foraging model that uses our measured filtration rates, takes into account spatial and seasonal variability in chl a concentrations, and allows consumption of zooplankton and detrital carbon in addition to phytoplankton (e.g. Durbin \& Durbin 1998, Luo et al. 2001).

Overall, the YOY and age-1+ findings support the results of several other studies of Atlantic menhaden ecology (Durbin \& Durbin 1975, 1998, Friedland et al. 1984, 2006) while providing empirically-derived models of responses that have not been previously described. The conclusion that YOY menhaden seem to be capable of ingesting much more primary production, while maintaining lower nitrogen excretion rates than age-1+ fish is common across studies. Therefore, in terms of Chesapeake Bay water quality, it is conceivable that age-1+ menhaden may exacerbate some of the problems associated with eutrophication through the potential enhancement of phytoplankton, while, at a localized scale, YOY menhaden may mitigate the effects. However, based on our estimates of bay-wide clearance rates and net nitrogen removal, it is likely that this mitigation plays a minor role within the bay ecosystem as a whole.

Acknowledgements. The authors thank E. Canuel, J. Olney, M. Fabrizio, C. Bonzek and D. Ward for guidance; B. Lawson, L. Ott, K. McNamee, A. Horodysky, J. Gartland, R. Johnson, A. Buchheister, A. Lynch, J. Smith, R. Boroghs, C. Magel and P. McGrath for animal husbandry, capture and experimental support. Also, thank you to T. Miller, K. Friedland and 3 anonymous reviewers for valuable comments on the manuscript. Funding was provided by EPA Chesapeake Bay Program (award CD-973256) and the Keith Campbell Foundation for the Environment. This is Virginia Institute of Marine Science contribution no. 3054

\section{LITERATURE CITED}

AFS (2004) Guidelines for the use of fishes in research. American Fisheries Society, Bethesda, MD

Ahrenholz DW (1991) Population biology and life history of the North American menhadens, Brevoortia spp. Mar Fish Rev 53:3-19

Akre BG, Johnson DM (1979) Switching and sigmoid functional response curves by damselfly naiads with alternative prey available. J Anim Ecol 48:703-720

ASMFC (2006) 2006 stock assessment report for Atlantic menhaden. Atlantic States Marine Fisheries Commission, Washington, DC

Båmstedt U, Gifford DJ, Irigoien X, Atkinson A, Roman M (2000) Expression of zooplankton feeding rates and common conversion factors. In: Harris RP, Wiebe PH, Lenz J, Skjoldal HR and Huntley M (eds) Zooplankton methodology manual. Academic, London, p 299-303

Boynton WR, Garber JH, Summers R, Kemp WM (1995) Inputs, transformations, and transport of nitrogen and phosphorus in Chesapeake Bay and selected tributaries. Estuaries 18:285-314

Bundy MH, Jacobs F, Bartell S, Zhang J (2006) Modeling effects of suspension-feeding zooplankton on water quality in Chesapeake Bay. Final report to the EPA Chesapeake Bay Program, Annapolis, MD

Burnham KP, Anderson DR (2002) Model selection and multimodel inference: A practical information-theoretic approach, 2nd edn. Springer-Verlag, New York

CBFEAP (Chesapeake Bay Fisheries Ecosystem Advisory Panel (National Oceanic and Atmospheric Administration)) (2006) Fisheries ecosystem planning for Chesapeake Bay. American Fisheries Society, Trends in Fisheries Science and Management 3, Bethesda, MD

CBP (Chesapeake Bay Program) (2000) Chesapeake 2000: A watershed partnership agreement. Chesapeake Bay Program, U.S. Environmental Protection Agency, Annapolis, $\mathrm{MD}$

Cerco CF, Noel MR (2004) Process-based primary production modeling in Chesapeake Bay. Mar Ecol Prog Ser 282: 45-58

> Dunbrack RL, Giguere LA (1987) Adaptive responses to accelerating costs of movement: A bioenergetics basis for the type-III functional response. Am Nat 130:147-160

Durbin AG, Durbin EG (1975) Grazing rates of the Atlantic menhaden Brevoortia tyrannus as a function of particle size and concentration. Mar Biol 33:265-277

Durbin AG, Durbin EG, Verity PG, Smayda TJ (1981) Voluntary swimming speeds and respiration rates of a filterfeeding planktivore, the Atlantic menhaden, Brevoortia tyrannus (Pisces: Clupeidae). Fish Bull 78:877-886

Durbin AG, Durbin EG (1998) Effects of menhaden predation on plankton populations in Narragansett Bay, Rhode Island. Estuaries 21:449-465

Durbin EG, Durbin AG (1981) Assimilation efficiency and nitrogen excretion of a filter-feeding planktivore, the Atlantic menhaden, Brevoortia tyrannus (Pisces: Clupeidae). Fish Bull 79:601-616

Edgar RK, Hoff JG (1976) Grazing of freshwater and estuarine benthic diatoms by adult Atlantic menhaden, Brevoortia tyrannus. Fish Bull 74:689-693

> Forward Jr RB, Reinsel KA, Peters DS, Tankersley RA and others (1999) Transport of fish larvae through a tidal inlet. Fish Oceanogr 8(Suppl. 2):153-172

> Friedland KD, Haas LW, Merriner JV (1984) Filtering rates of the juvenile Atlantic menhaden Brevoortia tyrannus (Pisces: Clupeidae), with consideration of the effects of detritus and swimming speed. Mar Biol 84:109-117 
Friedland KD, Ahrenholz DW, Smith JW, Manning M, Ryan J (2006) Sieving functional morphology of the gill raker feeding apparatus of Atlantic menhaden. J Exp Zool 305A:974-985

Fulford RS, Breitburg DL, Newell RIE, Kemp WM, Luckenbach M (2007) Effects of oyster population restoration strategies on phytoplankton biomass in Chesapeake Bay: A flexible modeling approach. Mar Ecol Prog Ser 336: $43-61$

Haas LW (1982) Improved epifluorescence microscopy for observing planktonic micro-organisms. Ann Inst Oceanogr 58:261-266

Hagy JD, Boynton WR, Keefe CW, Wood KV (2004) Hypoxia in Chesapeake Bay, 1950-2001: Long-term change in relation to nutrient loading and river flow. Estuaries 27: 634-658

Hartman KJ, Brandt SB (1995) Trophic resource partitioning, diets, and growth of sympatric estuarine predators. Trans Am Fish Soc 124:520-537

Harvey WH (1937) Note on selective feeding by Calanus. J Mar Biol Assoc 22:97-100

Hassell MP, Lawton JH, Beddington JR (1977) Sigmoid functional responses by invertebrate predators and parasitoids. J Anim Ecol 46:249-262

Higham JR, Nicholson WR (1964) Sexual maturation and spawning of Atlantic menhaden. Fish Bull 63:255-271

Hillebrand $\mathrm{H}$, Durselen CD, Kikrschtel D, Pollingher U, Zohary T (1999) Biovolume calculation for pelagic and benthic microalgae. J Phycol 35:403-424

Holling CS (1959) Some characteristics of simple types of predation and parasitism. Can Entomol 91:385-398

Holling CS (1965) The functional response of predators to prey density and its role in mimicry and population regulation. Mem Entomol Soc Can 45:1-60

Houde ED, Schekter RC (1980) Feeding by marine fish larvae: Developmental and functional responses. Environ Biol Fishes 5:315-334

ICPRB (Interstate Commission on the Potomac River Basin) (2008) Methodology applied in the calculation of Chesapeake Bay Program phytoplankton composite metrics and index of biotic integrity (PIBI). US EPA Chesapeake Bay Program, Annapolis, MD

Ivlev VS (1961) Experimental ecology of the feeding of fishes. Yale University Press, New Haven, CT

Jeffrey SW, Humphrey GF (1975) New spectrophotometric equations for determining chlorophylls $a, b, c$, and $c_{2}$ in higher plants, algae, and natural phytoplankton. Biochem Physiol Pflanz 167:191-194

Jeffries HP (1975) Diets of juvenile Atlantic menhaden (Brevoortia tyrannus) in three estuarine habitats as determined from fatty acid composition of gut contents. J Fish Res Board Can 32:587-592

Jeschke JM, Tollrian R, Kopp M (2002) Predator functional responses: Discriminating between handling and digesting prey. Ecol Monogr 72:95-112

Kemp WM, Boynton WR, Adolf JE, Boesch DF and others (2005) Eutrophication of Chesapeake Bay: Historical trends and ecological interactions. Mar Ecol Prog Ser 303:1-29

Kempf A, Floeter J, Temming A (2008) Predator-prey overlap induced Holling type III functional response in the North Sea fish assemblage. Mar Ecol Prog Ser 367: 295-308

Koen-Alonso M, Yodzis P (2005) Multispecies modelling of some components of the marine community of northern and central Patagonia, Argentina. Can J Fish Aquat Sci 62:1490-1512
Landry MR (1981) Switching between herbivory and carnivory by the planktonic marine copepod Calanus pacificus. Mar Biol 65:77-82

> Lewis VP, Peters DS (1984) Menhaden - a single step from vascular plant to fishery harvest. J Exp Mar Biol Ecol 84:95-100

- Lewis VP, Peters DS (1994) Diet of juvenile and adult Atlantic menhaden in estuarine and coastal habitats. Trans Am Fish Soc 123:803-810

Liao N (2002) Determination of ammonia in brackish or seawater by flow injection analysis. QuikChem Method 31107-0-1-B, Lachat Instruments, Milwaukee, WI

Luo J, Hartman KJ, Brandt SB, Cerco CF, Rippetoe TH (2001) A spatially-explicit approach for estimating carrying capacity: An application for the Atlantic menhaden (Brevoortia tyrannus) in Chesapeake Bay. Estuaries 24: $545-556$

> Márquez L, Caballos M, Domingues P (2007) Functional response of early stages of the cuttlefish Sepia officinalis preying on the mysid Mesopodopsis slabberi. Mar Biol Res 3:462-467

Marshall HG, Burchardt L, Lacouture R (2005) A review of phytoplankton composition within Chesapeake Bay and its tidal estuaries. J Plankton Res 27:1083-1102

McHugh JL (1967) Estuarine nekton. In: Lauff GH (ed) Estuaries. American Association for the Advancement of Science, Washington, DC, p 581-620

Miller TJ, Crowder LB, Rice JA, Binkowski FP (1992) Body size and the ontogeny of the functional response in fishes. Can J Fish Aquat Sci 49:805-812

Murdoch WW (1969) Switching in general predators: Experiments on predator specificity and stability of prey populations. Ecol Monogr 39:335-354

> Nicholson WR (1978) Movements and population structure of Atlantic menhaden indicated by tag returns. Estuaries $1: 141-150$

- Oaten A, Murdoch WW (1975) Switching, functional response, and stability in predator-prey systems. Am Nat 109:299-318

Oviatt CA, Gall AL, Nixon SW (1972) Environmental effects of Atlantic menhaden on surrounding waters. Chesapeake Sci 13:321-323

Peck JI (1893) On the food of the menhaden. Bull US Fish Comm 13:113-126

Peters DS, Schaaf WE (1981) Food requirements and sources for juvenile Atlantic menhaden. Trans Am Fish Soc 110: 317-324

- Quinlan JA, Blanton BO, Miller TJ, Werner FE (1999) From spawning grounds to the estuary: Using linked individual-based and hydrodynamic models to interpret patterns and processes in the oceanic phase of Atlantic menhaden Brevooritia tyrannus life history. Fish Oceanogr 8:224-246

Redfield A, Ketchum B, Richards F (1966) The influence of organisms on the composition of sea-water. In: Hill MN (ed) The sea. Wiley Interscience, New York, p 26-48

Reintjes JW (1969) Synopsis of biological data on the Atlantic menhaden, Brevoortia tyrannus. US Dept Inter Fish Wildl Serv FAO Species Synopsis No. 42:0-30

Richards SW (1963) The demersal fish population of Long Island Sound. II. food of the juveniles from a sand-shell locality (station I). Bull Bingham Oceanogr Collect 18: $32-72$

Rothschild BJ, Ault JS, Goulletquer P, Heral M (1994) Decline of the Chesapeake Bay oyster population: A century of habitat destruction and overfishing. Mar Ecol Prog Ser 111:29-39 
Sanderson SL, Cheer AY, Goodrich JS, Graziano JD, Callan WT (2001) Crossflow filtrations in suspension-feeding fishes. Nature 412:439-441

Schauber EM, Ostfeld RS, Jones CG (2004) Type 3 functional response of mice to gypsy moth pupae: Is it stabilizing? Oikos 107:592-602

Shoaf TW, Lium BW (1976) Improved extraction of chlorophyll $a$ and $b$ from algae using dimethyl sulfoxide. Limnol Oceanogr 21:926-928

Smayda TJ (1978) What to count? In: Sournia A (ed) Phyto- plankton manual. UNESCO, Paris, p 165-166

Smout $\mathrm{S}$, Lindstrøm U (2007) Multispecies functional response of the minke whale Balaenoptera acutorostrata based on smallscale foraging studies. Mar Ecol Prog Ser 341:277-291

- Wang L, Bisseleua DHB, You M, Huang J, Liu B (2006) Population dynamics and functional response of Citrostichus phyllocnistoides (Narayanan) (Hym., Eulophidae) on citrus leaf-miner, Phyllocnistis citrella Stainton (Lep., Phyllocnistidae) in Fuzhou region of South-East China. J Appl Entomol 130:96-102

Appendix 1. Additional experimental details

General. Pilot experiments using a range of densities of menhaden indicated that 15 YOY and 3 age- $1+$ fish were appropriate densities in terms of initiating a feeding response as well as preventing stress due to ammonia toxicity during experimentation. To prevent toxicity during the acclimation phase, a $150 \mathrm{l}$ water change was performed after $24 \mathrm{~h}$. Evaluation of stomachs from select fish following the $48 \mathrm{~h}$ acclimation period was also performed during pilot experiments, and it was confirmed that this time period was sufficient for allowing the evacuation of stomach contents.

Phytoplankton. Unfiltered York River water was added to the tanks using a seawater pump mounted on a nearby pier. Initial microscopic analysis of the unfiltered water indicated that the planktonic organisms were intact at the beginning of each experiment. There was minimal variability in the concentration of phytoplankton in the unfiltered water, so it was deemed ineffective to rely solely on ambient conditions to provide the range of concentrations needed for characterizing the functional response. To simulate various concentrations of phytoplankton blooms that menhaden may encounter in Chesapeake Bay, the unfiltered York River water was supplemented with a cultured diatom species (Thalassiosira weissflogii: cell size: $5-15 \mu \mathrm{m}$, concentration: $1 \times 10^{6}$ cells ml ${ }^{-1}$ - Reed Mariculture) native to Chesapeake Bay. The amount added was constant across all tanks within an experiment, but varied between experiments $(70 \mu \mathrm{l}$ to $40 \mathrm{ml}$ ) to achieve a wide range of total chl a concentrations $\left(3.9-203.2 \mu \mathrm{g} \mathrm{l}^{-1}\right)$.

All chl a values represented total chl $a$ and were not corrected for phaeophytin; pilot experiments indicated that menhaden did not distinguish between live and dead phytoplankton. Water samples for chl a were taken initially (0 min) and finally (360 min) within each tank, and were processed in triplicate by filtering $10 \mathrm{ml}$ per sample through a $25 \mathrm{~mm}, 0.7 \mu \mathrm{m}$ Whatman glass-fiber filter. Chl a concentrations were then determined by fluorometry using the acetone extraction method described by Shoaf \& Lium (1976) and the equations suggested by Jeffrey \& Humphrey (1975). Also, a YSI 6600 sonde (YSI) equipped with a fluorometer was used for monitoring chl a concentrations hourly throughout each experiment. These measurements were corrected to actual chl a by generating experiment-specific calibration curves that related fluorescence to the extracted chl a measurements.

Samples for phytoplankton counts were taken from each tank at the beginning and end of each experiment. The samples were fixed in glutaraldehyde, stained with DAPI, proflavind and calcoflour, and then counted using epifluo- rescence microscopy (Haas 1982). The initial percent composition of the phytoplankton community was then determined by classification and size-range for each experiment to compare the composition across the range of initial chl a concentrations. Also, cell counts in each taxonomic size group were converted to estimated carbon biomass using the Chesapeake Bay Program's (CBP) database of speciesspecific cellular carbon contents for all species occurring in the bay (ICPRB 2008). This database was derived by compiling measured cell dimensions of each species to compute cell volumes primarily using the geometric equations of Hillebrand et al. (1999), followed by conversion to carbon content using the equations of Smayda (1978) after correcting for vacuole volume in diatoms. All species within each taxonomic class (Coscinodiscophyceae, Cryptophycea, Cyanophyceae, and Dinophyceae) were extracted from the CBP database and used to regress cell carbon content against cell dimension (length or diameter as appropriate). These regressions were then used to compute cell carbon content for each taxonomic size category using the midpoint dimension. For diatoms, only the centric forms were used as these were by far the dominant type of diatom. Biomass of diatom and cyanobacterial chains was computed by multiplying the estimated chain length by the ratio of cell carbon to cell diameter for the smallest size category, as chains were generally made up of these smaller cells. Dinoflagellates were not distinguished between autotrophic and heterotrophic species.

Nitrogen excretion. Ammonium concentrations were measured in water samples collected every $2 \mathrm{~h}(0,2,4$ and $6 \mathrm{~h})$ during the experiments. All samples were filtered through a $0.45 \mu \mathrm{m}$ Puradisc syringe filter and frozen for later analysis on a Lachat Autoanalyzer (Lachat Instruments: Liao 2002). Each tank was treated as a single experimental unit, and all fish within a unit were assumed to excrete equal amounts of nitrogen at identical rates.

Additional experiment. Water samples were taken from each tank at the beginning $\left(t_{0}\right)$ and end $\left(t_{3}\right)$ of the experiment by removing $10 \mathrm{l}$ through the sampling valves. The sample was filtered through a $200 \mu \mathrm{m}$ sieve, and the material retained was preserved in $4 \%$ formalin for later counting. The concentration (number $\mathrm{l}^{-1}$ ) of zooplankton in each tank was estimated and clearance and ingestion rates were calculated using Eq. (1)-(4), where $C_{i}$ and $C_{f}$ were expressed as number $\mathrm{l}^{-1}$ rather than $\mu_{\mathrm{g}} \mathrm{l}^{-1}$. Also, additional water samples were taken from each tank at $0,1.5$ and $3 \mathrm{~h}$ for determining ammonium concentrations and calculating TDN-ex in the manner previously described. 